\title{
PREDICTION OF WATER-BASED PAINT PROPERTIES BASED ON THEIR MINERAL FILLERS: SIMPLEX-PLSR COUPLING APPLICATION
}

\author{
P. R. N. CONCEIÇÃO ${ }^{1}$, C. O. PETTER ${ }^{2}$, C. H. SAMPAIO ${ }^{3}$ \\ ${ }_{1,2,3}$ Universidade Federal do Rio Grande do Sul \\ paulo.conceicao@ufrgs.br ${ }^{1}$
}

Received 21/02/2018 - Accepted 02/04/2018

DOI: $10.15628 /$ holos.2018.6968

\begin{abstract}
The present study shows the optimization of mineral filler blends for use in water-based paints. The aim of the modelling is to evaluate the possibility of creating a model of prediction of the contrast ratio and brightness of the dry film, where the fillers that participate in the system are fillers used commercially by the paint industry. The differential of the use of the mixtures design, called Simplex, is that the predictions are made by carrying out a linear combination between the
\end{abstract}

proportions of the mineral fillers and the response variables. The proposed procedure consists in generating a numerical model that can predict final paint properties depending on the concentrations of the mineral fillers (PCC, GCC and kaolin) used. As support for simplex mixture design, the methods of Partial Least Squares regression and Response Surface were used in the calculations of the models and in the visualization of the response variables.

PALAVRAS-CHAVE: kaolin, carbonate, simplex mixture design, brightness, mineral processing.

\section{PREDIÇÃO DE PROPRIEDADES DE TINTA BASE ÁGUA EM FUNÇÃO DE SUAS CARGAS MINERAIS: APLICAÇÃO DE SIMPLEX-PLSR}

\section{RESUMO}

O presente estudo mostra a otimização de misturas de cargas minerais para uso em tintas base-água. 0 modelamento tem o objetivo de avaliar a possibilidade de criar um modelo de predição da razão de contraste e alvura da película seca, onde as cargas que participam do sistema são cargas usadas comercialmente pela indústria de tintas. O diferencial da utilização do planejamento de misturas, chamado Simplex, é que as predições são feitas realizando-se uma combinação linear entre as proporções das cargas minerais e as variáveis de resposta. O procedimento proposto consiste em gerar um modelo numérico que seja capaz de prever propriedades finais da tinta, em função das concentrações das cargas minerais utilizadas (PCC, GCC e caulim). Como suporte ao planejamento simplex, utilizou-se os métodos de Mínimos Quadrados Parciais e Superfície de Resposta nos cálculos dos modelos e na visualização das variáveis de resposta.

KEYWORDS: kaolin, carbonate, simplex mixture design, brightness, mineral processing. 


\section{INTRODUCTION}

In general, paints consist of resins, pigments, mineral fillers, solvents, dryers and additives (Carvalho, 2001; CETESB, 2006). There are several types of paints that use different concentrations of pigments and fillers, these concentrations can reach up to 50wt\% (Bartholi, 2001; Ciullo, 1996; Conceição, 2006) of the total paint, making the paint industry one of the largest consumers of mineral fillers in the world. The pigments and fillers are ultrafine solid particles, dispersed and insoluble in the paint. They are mainly responsible for the behaviour of layer appearance, colour, opacity, durability and mechanical strength of paint (Wilker, 2001). Pigments or active elements are those that provide colour and opacity. Mineral fillers or inert elements are those that provide certain properties, such as: decrease of brightness, aid in opacity, resistance and greater consistency (CETESB, 2006; Lambourne \& Strivens, 1999). Both the pigment and the mineral fillers are selected based on several features, such as: oil absorption, particle size and shape, light fastness, as well as the hidden power that is strongly influenced by factors such as refractive index (Fazenda, 1993). The mineral fillers improve the mechanical performance and surface finish of the products and they are responsible for important parameters in the formulation such as viscosity, hidden power, cost, etc. They are also called functional filler or mineral extender (Conceição, 2006; Conceição, Castro, \& Petter, 2006). In Brazil, the increase in the use of mineral fillers in the paint industry occurred in 1998, when mining companies began to follow world changes and paint manufacturers' demands for more homogeneous products (Scigliano, 1998). Thus, by increasing in the use of the fillers in the production of paint, it can be considered a way of reducing the cost of the formulation (Castro, Conceição, \& Petter, 2005; Lozasso, 2001).

Many different types of mineral fillers are used worldwide, derived from different geological formations, most commonly used ones are talc, kaolin, mica, barite, bentonite, quartz, diatomite, calcium carbonate (natural and precipitate) and also called those of regional like agalmatolite, characteristic of the Brazilian geological formation and adapted to the condition of local supply local (Occaa, 1983; Bartholi, 1998; Scigliano, 1998; Lambourne, 1999; Phillips, 1999; Bartholi, 2001; Hare, 2001; Perez, 2001; Ciullo, 2002; Ciullo, 2003; Dalpiaz et al., 2004; Vandelbilt, 2005). According to Associação Brasileira dos Fabricantes de Tintas [AFRAFATI] (2016), in Brazil, in 2015, 1.318 billion liters of paint were produced. Doing a relation between average amount of mineral filler and pigment per gallon (3.78 I) of paint, results in an estimated consumption of 672,000 tonnes of mineral fillers for the year 2015.

Most of mineral fillers are used only to reduce paint cost. The major challenge for mineral fillers producer to show how fillers can improve specific properties of paints, besides reduce cost (Conceição et al, 2009). According to Petter and Conceição (2009) in the paint industry, mineral fillers have a good performance if they do not suffer variations in raw material quality. Frequently that variation in quality occurs due to differences on the mineral processing applied by the several mineral fillers suppliers (Petter, Castro, \& Conceição, 2005). Since, many companies work with tinting systems that need mineral fillers with well-defined properties and without significance variations, the lack of such homogeneity could result in significant differences in the final properties of the paint. Therefore, any change in the supplier or properties of the raw material may cause damage to the final product, the paint. According to Castro, Conceição and 
Petter (2007) to solve the problem, suppliers of mineral fillers try to adjust the fillers according to the needs of the paint industry. In the search for this suitability, the most diverse physicalchemical treatments are employed.

Basis of the response surface is to find the relationship between control variables and response variables through a polynomial relationship (Bezerra et al., 2008). Moreover, second order models, in most cases, can have a good fit and in more complex cases cubic terms are used. In effect, using response surface involves fitting a regression model to response surface data (Bezerra et al., 2008; Box, \& Hunter, 1961). In this fit, estimating the parameters of the model are employed methods, as, for example, Ordinary Least Squares, Bayesian and Bootstrap. Advantage of using Partial Least Squares (PLS), in place of these methods, lies in the ability of PLS to perform a simultaneous decomposition on the dependent and independent variables and to calculate the regression coefficients for each dependent variable (Wold, 1973; Wold, Sjöström, \& Eriksson, 2001).

The proposal of this study is to show that the use of design of experiments of mixtures, called Simplex, coupling a partial least squares (PLS) alternatively to common algorithms can be used to optimize the properties of water-based paint according the mineral fillers properties inside the paint coating.

\section{MATERIALS AND METHODS}

\subsection{Manufacturing of paint}

The laboratory paints were made in a suitable container for a total volume of $1 / 4$ of a gallon $(900 \mathrm{ml})$, considering the complete mixture of all paint components. The paints were manufactured using a cowles type disperser on a bench shaker. In the present study, a waterbased white paint formulation was evaluated, containing the following percentages for the components: Resin $=11 \%$; Pigment $=38 \%\left(8 \% \mathrm{TiO}_{2}\right.$ and $30 \%$ filler $)$; Solvent $=48.5 \%$ water and Additives $=2.5 \%$ (dispersant, bactericide, biocide, defoamer, surfactant, thickener and coalescent). During the tests all the paint components (resin, solvent, additives and pigments primary and mineral filler or functional filler) remained constant. The only changes were the type of functional filler and combinations thereof. The applications, for subsequent measurement of parameters such as contrast ratio and brightness, were made in Leneta type cardboards, containing a black band, with a $100 \mu \mathrm{m}$ extender. In addition to these parameters, others were measured as PVC (pigment volume concentration), gloss, viscosity, stability, $\mathrm{pH}$. These parameters were chosen because they represent the main qualities that a coating with protective and decorative function should have, such as opacity, colour and stability. Since the opacity and brightness of the film were one of the most important properties of a paint, they were chosen to be modeled through the optimization of mixtures. The contrast ratio ranges from zero to 100 and is related to the hidden power. Thus, a contrast ratio equal to 100 means that the paint film can completely cover the substrate, without this influencing the reflection, that is, the colour that the observer sees. Conversely, low contrast ratios mean that the film cannot completely cover the substrate, so the reflectance will be influenced by the substrate. The contrast ratio (CR) has no units and is calculated from Equation (1): 


$$
C R(\%)=\frac{R_{p}}{R_{b}} x 100
$$

Where:

$\mathrm{Rp}=$ reflectance of the film under the black background.

$\mathrm{Rb}=$ reflectance of the film under the white background.

The brightness was determined on the dry film of the paint, by reading in Datacolor spectrophotometer Dataflash-100. The paint was applied on a white cardboard with a black strip, type Leneta, using a $100 \mu \mathrm{m}$ thick extender.

Mineral fillers, traditionally used by the paint industry, were used in modelling (Conceição \& Petter, 2000). The chosen fillers were: precipitated calcium carbonate (PCC), ground calcium carbonate (GCC) and kaolin (KAO).

\subsection{Multivariate data regression - Partial Least Squares}

Partial Least Squares Regression (PLS-R) is a widespread method for reducing and combines two sets of variables (Conceição \& Petter, 2007). PLS can fit several response variables in an individual model by means of Nonlinear Iterative Partial Least Squares (NIPALS) algorithm (Wold, 1969, 1973, 2001). PLS regression transforms the original variables in a set of uncorrelated new variables and apply least squares regression on these new set. The algorithm decomposes $\mathbf{X}$ and $\mathbf{Y}$ in a set of orthogonal factors, in this case known as latent variables, plus a residue matrix corresponding to the non-modelled data. Latent variables, such as the main components, can be represented as the product of the score and loading vectors or as the product of the matrices in which these vectors were grouped. The independent variables are decomposed as $\mathbf{X}=\mathbf{T P}^{\top}+\mathbf{E}$ with $\mathbf{T}$ being the scores matrix, $\mathbf{P}$ being the loading matrix and $\mathbf{E}$ being the residue. Likewise, the dependent variables are decomposed as $\mathbf{Y}=\mathbf{U} \mathbf{Q}^{\top}+\mathbf{F}$ and $\mathbf{U}$ are the scores, $\mathbf{Q}$ are the loadings and $\mathbf{F}$ are the residue. PLS establishes the relationship between the two data blocks by regressing the scores of the $\mathbf{X}$ block on the scores of the $\mathbf{Y}$ block using a regression coefficient $b$ to describe a linear function between these blocks, $\mathbf{U}=$ bT. Obtaining the best correlation between these matrices, with the smallest residuals described in the matrices $\mathbf{E}$ and $\mathbf{F}$, the scores of the matrix $\mathbf{T}$ are adjusted to simultaneously describe the matrix $\mathbf{Y}$. This is the basic algorithm of the partial least squares regression, which corresponds to PLS-1. Finally, $\mathbf{Y}$ is estimated for $\mathbf{Y}_{\text {est }}=$ TBC $^{\top}$ where $\mathbf{B}$ is the diagonal matrix of regression weights and $\mathbf{C}$ is weight matrix of Y (Wold et al., 2001; Esbensen et al., 2002; Kettaneh et al., 2005; Conceição, 2006; Mehmood et al., 2012). Some changes can be made to suit this method for different situations. In PLS-1, only one property of interest is considered in each model. However, when there is more than one property of interest to be calibrated using the same set of instrumental measures, the algorithm to be employed is PLS-2, in which the matrix of scores, $\mathbf{U}$, will be obtained to describe the properties of interest simultaneously. This method is interesting in situations where the 
properties of interest are correlated. In these two cases, it is assumed that the relationship between the data blocks $\mathbf{X}$ and $\mathbf{Y}$ is best described through a linear function. In PLS there is a compromise between explaining the variance in $\mathbf{X}$ and obtaining the highest correlation with $\mathbf{Y}$ (Conceição, 2006; Esbensen,2000; Esbensen et al., 2002; Wold, 1973; Wold, Sjöström, \& Eriksson, 2001).

\subsection{Design of experiments of mixtures - Simplex}

2.4 Mixture designs are used when the response variables change as a function of the relative proportions of the components and there are different designs like Screening and Optimal. Simplex designs were well described by Barros Neto et al. (1995), Esbensen, (2000), Esbensen et al. (2002), Conceição (2006), Conceição et al, (2006) and Chen (2010) and it is a special case in mixture designs and require the components sum to be the same for all proportions. In the present study was used the Simplex Designs to optimize final properties of a paint formulation and it means, the ternary mixture has a constraint that $X_{1}+X_{2}+X_{3}=1$, considering $X$ as mineral fillers proportions and $Y$ as response variables. Equation (2) is the general representation of a mixture model:

$$
\hat{y}=b_{0}+\sum_{i=1}^{3} b_{i} x_{i}+\sum_{i \leq j}^{3} \sum^{3} b_{i j} x_{i} x_{j}+\sum_{i \leq}^{3} \sum_{j}^{3} \sum_{\leq k}^{3} b_{i j k} x_{i} x_{j} x_{k}
$$

The parameter $\mathrm{i}$ in the above equation represents the response to the pure mixture, ij binary mixtures, and ijk ternary blends.

Table 1 shows the schematic representation of the tests and Figure 1 shows the position in the triangle representing simplex design. Assay1 through Assay3 represent paints in which only one filler has been incorporated into the formulation. About applications in practice, paints with only one mineral filler or extender are practically absent. Despite this, these paints were made so that it was possible to determine the effect of the charge alone on the final properties of the paint and to better develop the model. Geometrically, the Assay4 to Assay6 are binary compositions having equal proportions for the components and they are located on the edges of the triangle. Assay7 through Assay9 configure combinations of the three components. These represent points inside the triangle and they are used for model validation. Assay10 ( $a, b$ and $c)$ is the centroid, where the percentage of components have the same value. In three mixtures replicates were made to have an estimate of the repeatability and to test the significance of the adjusted coefficients. The assays were performed in a random manner in order to reduce the effects of noise.

Table 1: Simplex design - proportions of the mixtures and their position in the triangle, $b$ and $c$ are replicates.

\begin{tabular}{c|c|c|c|c|c}
\hline Assay & Mixture & Simplex & $\mathbf{X}_{\mathbf{1}}$ & $\mathbf{X}_{\mathbf{2}}$ & $\mathbf{X}_{\mathbf{3}}$ \\
\hline Assay1 & Pure & Vertex1a & 1 & 0 & 0 \\
Assay2 & Pure & Vertex2a & 0 & 1 & 0
\end{tabular}




\begin{tabular}{c|c|c|c|c|c} 
Assay3 & Pure & Vertex3a & 0 & 0 & 1 \\
Assay4a & Binary & Edge1a & 0.5 & 0.5 & 0 \\
Assay4b & Binary & Edge1b & 0.5 & 0.5 & 0 \\
Assay5a & Binary & Edge2a & 0.5 & 0 & 0.5 \\
Assay5b & Binary & Edge2b & 0.5 & 0 & 0.5 \\
Assay6a & Binary & Edge3a & 0 & 0.5 & 0.5 \\
Assay6b & Binary & Edge3b & 0 & 0.5 & 0.5 \\
Assay7 & Ternary & Axis1a & 0.667 & 0.167 & 0.167 \\
Assay8 & Ternary & Axis2a & 0.167 & 0.667 & 0.167 \\
Assay9 & Ternary & Axis3a & 0.167 & 0.167 & 0.667 \\
Assay10a & Ternary & Centroid-a & 0.333 & 0.333 & 0.333 \\
Assay10b & Ternary & Centroid-b & 0.333 & 0.333 & 0.333 \\
Assay10c & Ternary & Centroid-c & 0.333 & 0.333 & 0.333 \\
\hline
\end{tabular}

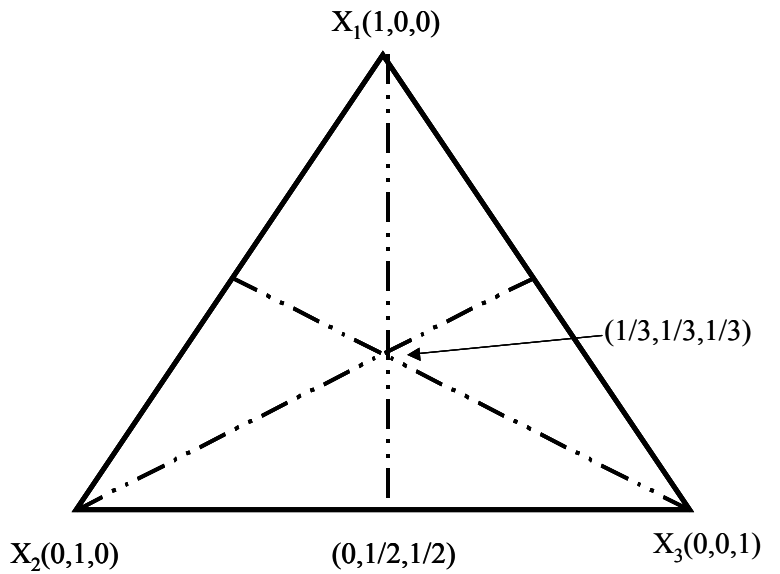

Figure 1: Triangular diagram of the compositions showing the coordinates for the Simplex.

\section{RESULTS}

The simplex design for PCC, GCC and KAO is evaluated as a function of the response variables (RV) of dry film contrast ratio (CR) and dry film brightness (BRT).

Table 2 shows the 15 paints produced with the respective control variables (percentages of minerals - PCC, GCC and KAO), as well as the response variables (CR, BRT) and the results for the simplex containing the PCC, GCC and KAO. The values for the response variables are mean values of three measurements for each sample. The matrix $\mathbf{X}$ with the independent variables is formed by the variables $X_{1}, X_{2}$ and $X_{3}$, that is, the percentages of the mineral fillers inside the paint. Likewise, the matrix $\mathbf{Y}$ is formed by the response variables $Y_{1}$ and $Y_{2}$, dry film contrast ratio and brightness.

Table 2: Simplex design with the response variables for commercial kaolin, $C R=$ dry film contrast ratio, BRT = dry film brightness, $b=$ replicas, $c=$ replica.

\begin{tabular}{|c|c|c|c|c|c|}
\hline Assay & $\begin{array}{c}\mathrm{X}_{1} \\
\mathrm{PCC}\end{array}$ & $\begin{array}{c}X_{2} \\
\text { GCC }\end{array}$ & $\begin{array}{c}X_{3} \\
\text { KAO }\end{array}$ & $\begin{array}{c}Y_{1} \\
\text { CR (\%) }\end{array}$ & $\begin{array}{c}Y_{2} \\
\text { BRT (\%) }\end{array}$ \\
\hline Vertex1a & 1 & 0 & 0 & 95.37 & 90.29 \\
\hline Vertex2a & 0 & 1 & 0 & 68.51 & 83.53 \\
\hline
\end{tabular}




\begin{tabular}{c|c|c|c|c|c} 
Vertex3a & 0 & 0 & 1 & 93.40 & 87.69 \\
Edge1a & 0.5 & 0.5 & 0 & 91.70 & 88.01 \\
Edge1b & 0.5 & 0.5 & 0 & 92.63 & 88.21 \\
Edge2a & 0.5 & 0 & 0.5 & 94.98 & 90.59 \\
Edge2b & 0.5 & 0 & 0.5 & 94.18 & 90.11 \\
Edge3a & 0 & 0.5 & 0.5 & 83.99 & 85.79 \\
Edge3b & 0 & 0.5 & 0.5 & 84.64 & 85.98 \\
Axis1a & 0.667 & 0.167 & 0.167 & 94.77 & 90.27 \\
Axis2a & 0.167 & 0.667 & 0.167 & 82.56 & 85.91 \\
Axis3a & 0.167 & 0.167 & 0.667 & 93.16 & 88.61 \\
Centroid-a & 0.333 & 0.333 & 0.333 & 92.39 & 88.28 \\
Centroid-b & 0.333 & 0.333 & 0.333 & 91.52 & 87.72 \\
Centroid-c & 0.333 & 0.333 & 0.333 & 91.93 & 87.96 \\
\hline
\end{tabular}

The proposed procedure consists of generating a numerical model, correlating the control variables $\mathbf{X}$ with the response variables $\mathbf{Y}$. In other words, based on the mass concentrations of each mineral fillers the model must be able to predict final paint properties. The methodology is developed by the application of simplex design. As support for the simplex, the Partial Least Squares (PLS) was used to correlate the matrix $\mathbf{X}$ with the matrix $\mathbf{Y}$ and the Response Surface Method (RSM) was used to visualize the response variables (Box \& wilson, 1951; Box \& Hunter, 1957, 1961; Bezerra, 2008; Myers et al., 2016). In modeling, at first it was tested a linear model with only the pure components, but this model has no predictive accuracy and then a quadratic model was used. However, both were not adequate to demonstrate the behavior of the response variables. Then it was evaluated a special cubic model that showed the best fit. The reason for this model to have predictive power is because in the special cubic model are considered the three vertices, the three edges and their replicates and the centroid of the triangle, which is composed of three measurements, containing equal proportions of the three components. To verify the performance of the model, external validation was performed with three validation points that were not part of the modeling. The points were named Axis1a, Axis2a and Axis3a. The analysis of statistical significance of the models was made using analysis of variance, Sum of Squares, Lack of Fit test and R-Squared. Tables 3 and 4 show the model summary statistics for the two response variables $\mathrm{CR}$ and $\mathrm{BRT}$

Table 3 shows the select models for CR, the Quadratic model was selected because it was the highest order polynomial where the additional terms are significant, the model was not aliased and had insignificant lack-of-fit, maximized Adjusted R-Squared and Predicted R-Squared, lower standard deviation (Std.Dev) and lower PRESS. In the Table 4 the same summary shows for BRT variable. The Quadratic model was selected due to it was the highest order polynomial where the additional terms are significant, the model was not aliased and had insignificant lackof-fit and maximized Adjusted R-Squared and Predicted R-Squared. In addition, both models had the lowest value for PRESS statistic.

Table 3: Model Summary Statistics for CR

\begin{tabular}{c|c|c|c|c|c|c|c}
\hline Source & $\begin{array}{c}\text { Sequential } \\
\text { p-value }\end{array}$ & $\begin{array}{c}\text { Lack of Fit } \\
\text { p-value }\end{array}$ & R-Squared & $\begin{array}{c}\text { Adjusted } \\
\text { R-Squared }\end{array}$ & $\begin{array}{c}\text { Predicted } \\
\text { R-Squared }\end{array}$ & Std. Dev. & PRESS \\
\hline
\end{tabular}




\begin{tabular}{c|c|c|c|c|c|c|c}
\hline Linear & 0.000564 & $2.174 \mathrm{E}-05$ & 0.8459 & 0.8074 & 0.7263 & 4.48 & 285.08 \\
Quadratic & $2.333 \mathrm{E}-06$ & 0.2085952 & 0.9994 & 0.9987 & 0.9946 & 0.37 & 5.67 \\
Spcl. Cubic & 0.208595 & - & 0.9996 & 0.9990 & - & 0.33 & - \\
\hline
\end{tabular}

Table 4: Model Summary Statistics for BRT

\begin{tabular}{c|c|c|l|l|l|l|c}
\hline Source & $\begin{array}{c}\text { Sequential } \\
\text { p-value }\end{array}$ & $\begin{array}{c}\text { Lack of Fit } \\
\text { p-value }\end{array}$ & R-Squared & $\begin{array}{c}\text { Adjusted } \\
\text { R-Squared }\end{array}$ & $\begin{array}{c}\text { Predicted } \\
\text { R-Squared }\end{array}$ & Std. Dev. & PRESS \\
\hline Linear & $1.861 \mathrm{E}-05$ & $7.494 \mathrm{E}-05$ & 0.9343 & 0.9179 & 0.8799 & 0.71 & 7.31 \\
Quadratic & $3.627 \mathrm{E}-05$ & 0.069239 & 0.9992 & 0.9983 & 0.9903 & 0.10 & 0.59 \\
Spcl. Cubic & 0.069239 & - & 0.9997 & 0.9992 & - & 0.07 & - \\
\hline
\end{tabular}

Verifying the significance of the regression coefficients, the standard deviation was calculated or standard error for each coefficient. The calculation of the uncertainties in the parameter estimates was developed by Conceição (2006). Table 5 shows the coefficients for the two response variables with the respective standard errors and the confidence interval for them.

For the two models, since the standard error of the $\mathrm{X}_{1} \mathrm{X}_{2} \mathrm{X}_{3}$ interaction in a special cubic model was greater than the coefficient estimate, it was chosen to leave it out of the equation which resulted in a quadratic model as in the summary statistics.

Table 5: Statistics for the terms of CR and BRT equations

\begin{tabular}{c|c|c|c|c|c|c}
\hline & $\mathbf{P C C}$ & $\mathbf{G C C}$ & $\begin{array}{c}\text { KAO } \\
\mathbf{X}_{\mathbf{3}}\end{array}$ & $\begin{array}{c}\text { PCC*GCC } \\
\mathbf{X}_{\mathbf{1}} \mathbf{X}_{\mathbf{2}}\end{array}$ & $\begin{array}{c}\text { PCC*KAO } \\
\mathbf{X}_{\mathbf{1}} \mathbf{X}_{\mathbf{3}}\end{array}$ & $\begin{array}{c}\mathbf{G C C} \mathbf{X}_{\mathbf{2}} \\
\mathbf{X}_{\mathbf{2}} \mathbf{X}_{\mathbf{3}}\end{array}$ \\
\hline CR model & & & & & & \\
coef_bi_CR & 95.35 & 68.48 & 93.38 & 41.35 & 1.98 & 12.94 \\
STDError & 0.26 & 0.26 & 0.26 & 1.23 & 1.53 & 1.53 \\
$95 \% \mathrm{Cl}-$ & 94.68 & 67.82 & 92.71 & 38.19 & -1.95 & 9.01 \\
$95 \% \mathrm{Cl}+$ & 96.01 & 69.15 & 94.04 & 44.50 & 5.92 & 16.88 \\
& & & & & & \\
BRT model & & & & & & \\
coef_bi_BRT & 90.30 & 83.54 & 87.69 & 4.64 & 6.12 & 0.44 \\
STDError & 0.07 & 0.07 & 0.07 & 0.34 & 0.42 & 0.42 \\
$95 \% C l-$ & 90.12 & 83.36 & 87.52 & 3.78 & 5.04 & -0.64 \\
$95 \% C l+$ & 83.72 & 87.88 & 87,10 & 5.51 & 7.19 & 1.51 \\
\hline
\end{tabular}

Equations (3) and (4) represent the models for CR (special cubic) and BRT (quadratic).

Quadratic model for CR

$C R_{e s t}(\%)=95.35 P C C+68.48 G C C+93.38 K A O+41.35 P C C \times G C C+1.98 P C C \times K A O+12.94 G C C \times K A O$

Quadratic model for BRT

$B R T_{\text {est }}(\%)=90.30 P C C+83.54 G C C+87.69 K A O+4.64 P C C \times G C C+6.12 P C C \times K A O+0.44 G C C \times K A O$ 
One of the great advantages of simplex design is that the constraint PCC + GCC + KAO = 1 allows the response variables to be visualized on a response surface. In addition, the visualization of the interaction between the mineral fillers is also visible. Any combinations of the three components can be easily calculated with the equations or with the response surfaces.

Figures 2 and 3 show the response surfaces for the response variables and the design points represent the assays in Table 2. In Figure 2, if one selects a target for CR as $90 \%$, for example, combinations of the three fillers that achieve $C R$ values above $90 \%$ could be generated with the mixtures that are in the reddish area of the response surface.

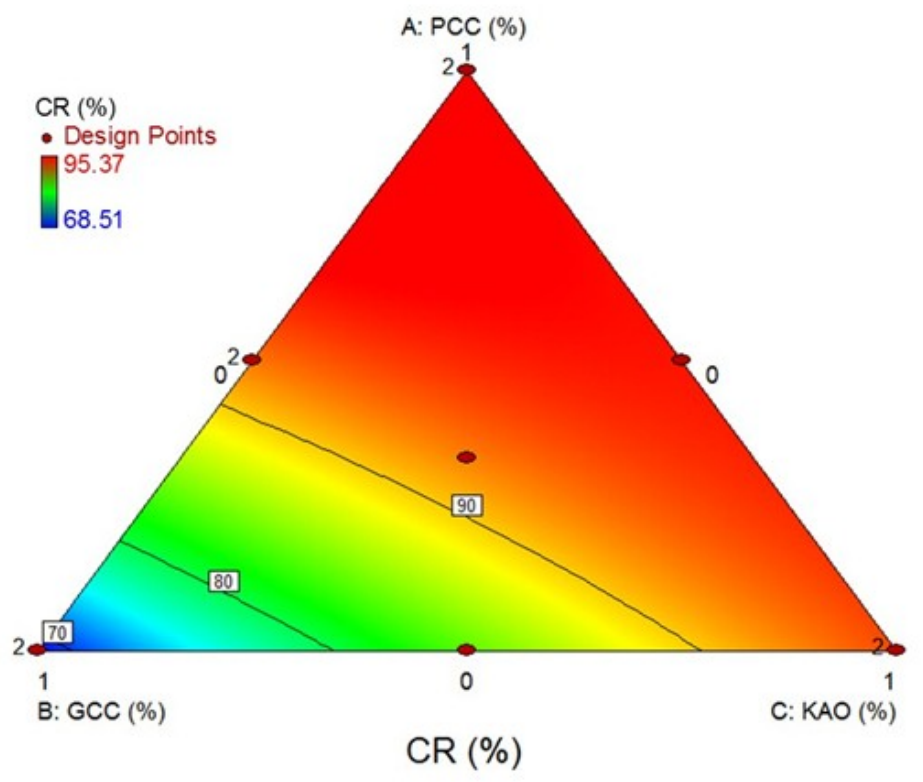

Figure 2: Response surface for CR.

The same is true for the BRT variable. If the target were values of brightness above $90 \%$, the combinations of fillers that should be used would be in the reddish area delimited by the line marking 90, Figure 3. 


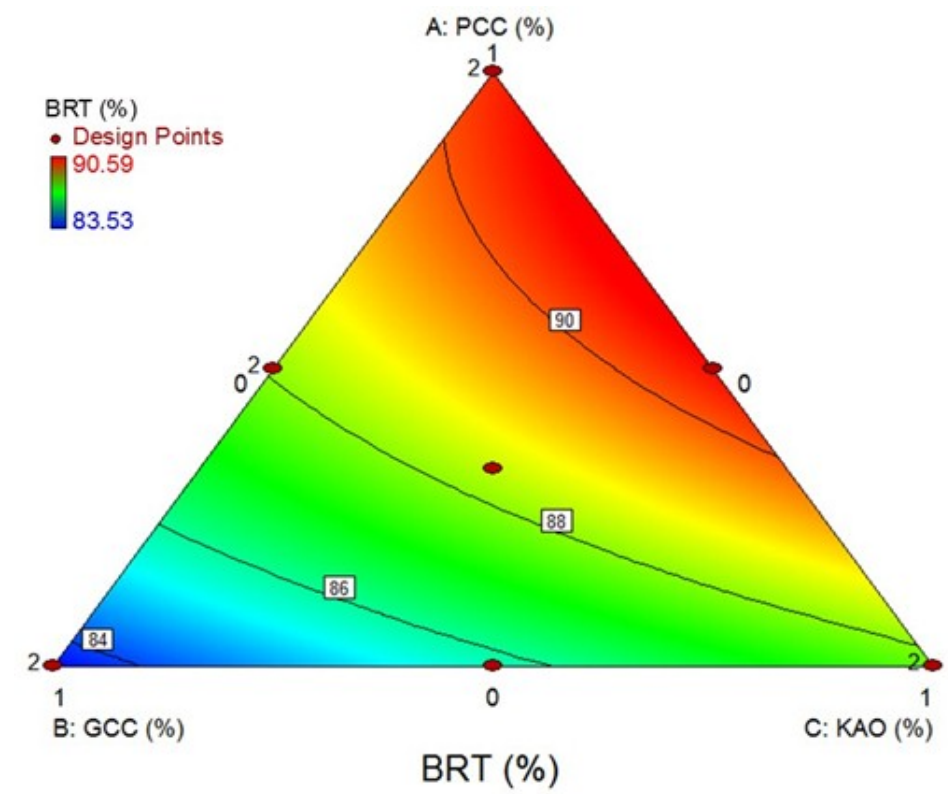

Figure 3: Response surface for the dry film of BRT

\subsection{Validation}

The validation of the multivariate calibration model was performed based on the analysis of the equations proposed in the calibration phase. Which certifies that the proposed model is reliable and meets the conditions described by the statistical parameters of Table 5 .

In the validation of the quadratic models for the two response variables, three samples were evaluated. Equations (3) and (4) were used to test the predictive power of models with samples that were not part of the calibration set. Table 6 presents the results for the validation of the models. The values of PCC, GCC and KAO are the contribution of each component in the mixture to make the paint. The values calculated by the models are in agreement with the confidence interval and with the standard error that were shown in Table 5 and the Root Mean Square Error of Prediction (RMSEP) (Conceição, 2006) calculated for the variables were 0.80 for CR and 0.28 for BRT.

Table 6: Validation for three internal surface points.

\begin{tabular}{c|c|c|c|c|c|c}
\hline PCC & GCC & KAO & CR_pred & CR_obser & BRT_pred & BRT_obser \\
\hline 0.667 & 0.167 & 0.167 & 95.72 & 94.77 & 89.95 & 90.27 \\
0.167 & 0.667 & 0.167 & 83.20 & 82.56 & 86.09 & 85.91 \\
0.167 & 0.167 & 0.667 & 92.36 & 93.16 & 88.29 & 88.61 \\
\hline
\end{tabular}

\subsection{Discussion}

The use of design of experiments of mixtures, with the restriction that the sum of the proportions of the participating elements is a constant, makes the properties of the mixture essentially dependent on the proportions of the components of this mixture. The finding of the 
maximum or minimum regions of the mixture is directly linked to the synergy of the constituent elements of the mixture and can be found by analyzing the response surfaces of each response variable. Applying this design of experiment, the paints with single mineral filler allow to observe the main effects of each constituent, on the other hand, the binary and ternary mixtures allow to evaluate the interactions of these minerals. As a result, a response surface is obtained for each paint response variable and these are functions of the mineral proportions inside the paint. The models presented, as well as the analysis of variance (test F) and validation proved the effectiveness of the design of mixtures. In a design of experiments, where, usually for the sake of financial and time savings, each factor is studied only in two levels (for example, $2^{\mathrm{k}}$ ), the results can generate an imprecise conclusion of the real functional link that connects the response of the system under study with the influencing factors. Additional information is always required. However, it is necessary to reconcile the number of trials with cost, time and results expected to be achieved.

The use of mixture designs can help to ensure that the lack of homogeneity in the mineral filler is corrected using the response surface, since it provides different combinations between the minerals that provide the same value for the response variables. The methodology can also be used to make comparisons between results of different mixtures with different mineral loads.

For instance, the comparison between the results with mixtures involving minerals that are not commonly employed, in order to discover minerals fillers that act as substitutes or partial or total extenders of fillers traditionally employed.

\section{CONCLUSIONS}

In this study precipitated calcium carbonate, ground calcium carbonate and kaolin were used as the mineral components of a water-based paint formulation. Through the combined use of Partial Least Squares and Simplex Design of mixtures a model was created to relate the amounts of the minerals to the properties of the dry film of the paint.

According to the results, it is concluded that it is possible to predict the contrast ratio and brightness of a water-based paint based on the quantities of mineral filler used in that paint. Using the equations of a quadratic model which represent the studied system it is possible to predict the value of the contrast ratio and brightness for any combinations of the mineral fillers used. Besides that, applying this methodology one can observe the main effects of each mineral and the binary and ternary interactions. In addition, it is possible optimize the results of all responses at the same time. Thus, saving time, because with few assays it is possible to define a very large number of combinations of the same fillers that generate different final characteristics for the paint, and with that there is a reduction of costs.

\section{ACKOWLEDGMENT}

The authors would like to thank the Federal University of Rio Grande do Sul and the National Council for Scientific and Technological Development (CNPq) for their research support. 


\section{REFERENCES}

Associação Brasileira dos Fabricantes de Tintas - AFRAFATI. (2016). Cartilhas e manuais, notícias e artigos. https://www.abrafati.com.br/publicacoes/cartilhas-e-manuais/ (accessed 31.10.2017)

Barros Neto, B., Scarmínio, I.S., Bruns, R.E. (1995). Planejamento e Otimização de Experimentos, 2 ed. Campinas, Ed. Unicamp, 299p.

Bartholi, J.C., (2001). Guia prático de aditivos minerais e suas aplicações em tintas, Minérios Ouro Branco, 2 Ed, agosto, $54 \mathrm{p}$.

Bartholi, J.C. (1998). Guia prático sobre cargas minerais e suas aplicações em tintas, Tintas e vernizes, agosto/setembro, 52-55 $\mathrm{p}$.

Bezerra, M.A., Santelli, R.E., Oliveira, E.P., Villar, L.S., Escaleira, L.A. (2008). Response surface methodology (RSM) as a tool for optimization in analytical chemistry, Talanta 76, 965-977.

Box, G. E., Hunter, J. S. (1957). Multi-factor experimental designs for exploring response surfaces. The Annals of Mathematical Statistics, 28, 195-241.

Box, G. E., Hunter, J. S. (1961). The 2k-p fractional factorial designs. Technometrics, 3(3), 311351.

Box, G. E.; Wilson, K. B. (1951). On the experimental attainment of optimum conditions. Journal of the Royal Statistical Society. Series B (Methodological), 13(1), 1-45.

Carvalho, G.A. (2001). Tintas e vernizes, Apostila de Materiais Poliméricos, UCS, CCET, DENQ.

Castro, C.D., Conceição, P.R.N., Petter, C.O. (2005). Estudo da influência de diferentes cargas minerais no processo de fabricação de tintas. In: XXI Encontro Nacional de Tratamento de Minérios e Metalurgia Extrativa, Natal/RN. XXI Encontro Nacional de Tratamento de Minérios e Metalurgia Extrativa. Natal/RN: O2 Editora. v. $2^{\circ}$. p. 496-503.

Castro, C.D., Conceição, P.R.N., Petter, C.O. (2007). Estudo de diferentes propriedades de cargas minerais para utilização da indústria de tintas. In: XXII ENTMME, Ouro Preto. XXII Encontro Nacional de Tratamento de Minérios e Metalurgia Extrativa. Ouro Preto: UFOP, v. 1. p. 731738.

CETESB - Companhia de Tecnologia de Saneamento Ambiental. (2006). Tintas e Vernizes - Guia técnico ambiental tintas e vernizes - Série $P+L, 70 p$.

Chen, R., Zhang, Z., Feng, C., Huc, K., Li, M., Li, Y., Shimizu, K., Chen, N., Sugiura, N. (2010). Application of simplex-centroid mixture design in developing and optimizing ceramic adsorbent for As (V) removal from water solution, Microporous and Mesoporous Materials $131,115-121$

Ciullo, P.A. (1996). Industrial minerals and their uses: a handbook and formulary. Westwood: Noyes Publications, $632 \mathrm{p}$.

Ciullo, P.A. (2002). Functional Silicate Fillers: Basic Principles, Paint \& Coating Industry, agosto, 30-36 p. 
Ciullo, P.A. (2003). Kaolin Clay: Functional optical additives, Paint \& Coating Industry, agosto, 42$47 \mathrm{p}$.

Conceição, P.R.N. (2006). Utilização de análise multivariada de dados na otimização de misturas de minerais industriais para a formulação de tintas, Tese, PPGEM/UFRGS, Porto Alegre. DOI: 10.13140/RG.2.1.1771.6960

Conceicao, P.R.N, Comim, K.O., Petter, C.O. (2001). Determinação do espectro de reflectância de misturas de caulim através da Função de Kubelka-Munk. Rem, Rev. Esc. Minas [online]., vol.54, n.4, pp.281-286. http://dx.doi.org/10.1590/S0370-44672001000400008.

Conceição, P.R.N., Castro, C.D., Petter, C.O. (2006). Utilização de Análise Multivariada de Dados na Escolha de Minerais Industriais para a Indústria de Tintas. In: In: 17 CBECiMat - Congresso Brasileiro de Engenharia e Ciência dos Materiais, Foz do Iguaçu. 17 CBECiMat - Congresso Brasileiro de Engenharia e Ciência dos Materiais.

Conceição, P.R.N., Castro, C.D., Petter, C.O. (2007). Seleção de cargas minerais através de análise em componentes principais. In: XXII ENTMME, 2007, Ouro Preto. XXII Encontro Nacional de Tratamento de Minérios e Metalurgia Extrativa. Ouro Preto: UFOP, v. 1. p. 775-782.

Conceição, P.R.N., PETTER, C.O. (2000). Utilização de técnicas espectro-colorimétricas no auxílio à lavra seletiva de caulins: adição de espectros de reflectância. Revista da Escola de Minas Rem, Ouro Preto/MG, v. 53, n.2, p. 125-128.

Conceição, P.R.N., Petter, C.O. (2007). Utilization of multivariate data analysis in fillers selection for paint industry, Nurnberg Congress - Europe's leading congress on coatings, ink, Adhesives, sealants, construction chemicals.

Conceição, P.R.N., Petter, C.O., Pampolha, M., Castro, C.D. (2009). Planejamento simplex, criofraturamento e interferometria na otimização de misturas de cargas minerais para a indústria de tintas. In: In: International Coatings Congress - XI International Coatings Congress, São Paulo. XI International Coatings Congress, ABRAFATI.

Dalpiaz, G., Corrêia, A. G., Conceição, P.R.N.; Bergeret, A., Fambri, L., Petter, C.O. (2004). Utilização de projetos de experimentos na análise de parâmetros de incorporação de calcários micronizados em compósitos. In: XX ENTMME, Florianópolis. XX ENTMME. Florianópolis: UNESC, v. 2. p. 333-340.

Esbensen, K.H., 2000. Multivariate data analysis - In practice, CAMO, 4th ed, $600 \mathrm{p}$.

Esbensen, K.H., Guyot, D., Westad, F., Houmoller, L.P. (2002). Multivariate Data Analysis: In Practice: An Introduction to Multivariate data analysis and experimental design, 5th Edition, $598 p$.

Fazenda, J.R. (1993). Tintas e vernizes - Ciência e tecnologia, ABRAFATI, volumes I (616 p) e II (1199 p), São Paulo.

Ferreira, S. L. C., Bruns, R. E., da Silva, E. G. P., dos Santos, W. N. L., Quintella, C. M., David, J. M. et al. (2007). Statistical designs and response surface techniques for the optimization of chromatographic systems. Journal of Chromatography A, 1158(1-2), 2-14.

Kettaneh, N., Berglund, A., Wold, S. (2005). PCA and PLS with very large data sets, Computational Statistics \& Data Analysis, Volume 48, 1, 69-85.

Kreutz, S. (2001). Perspectivas promissoras para o mercado de sistema tintométrico, Tintas e vernizes, dezembro/janeiro, 12-21 p. 
Lambourne, R, Strivens, T.A. (1999). Paint and Surface Coatings: Theory and Practice, 2nd Ed.

Lozasso, G. (2001). Cargas minerais em expansão, Tintas e vernizes, fevereiro/março, p, 10-17.

Occaa. (1983). Surface coatings - Raw materials and their usage, volume I, Australia, 408 p.

Perez, B.C. (2001). As rochas e os minerais industriais como elementos de desenvolvimento sustentável, Rio de Janeiro, CETEM/MCT, 37 p.

Petter, C.O., Castro, C.D., Conceição, P.R.N. (2005). Estudo da influência de diferentes cargas minerais no processo de fabricação de tintas. In: XXI ENTMME, Natal. Anais do XXI Encontro Nacional de Tratamento de Minérios e Metalurgia Extrativa. v. 2. p. 496-503.

Petter, C.O., Conceição, P.R.N. (2009). Otimização de mistura de cargas minerais para o uso na indústria de tintas. In: XXIII Encontro Nacional de Tratamento de Minérios e Metalurgia Extrativa, Gramado. XXIII Encontro Nacional de Tratamento de Minérios e Metalurgia Extrativa. Porto Alegre: Pallotti Gráfica e Editora, v. 2. p. 611-628.

Phillips, K.A. (1999). Industrial minerals in Arizona's paint industry, Arizona Department of Mines \& Mineral Resources, Open file report, $9 \mathrm{p}$.

Mehmood, T., Liland, K.H., Snipen, L., Sæbø, S. (2012). A review of variable selection methods in Partial Least Squares Regression, Chemometrics and Intelligent Laboratory Systems, 118, 6269.

Myers, R.H., Montgomery, D.C., Anderson-Cook, C.M. (2016). Response Surface Methodology: Process and Product Optimization Using Designed Experiments, 4th Edition, 856p.

Scigliano, S. (1998). A explosão das cargas minerais, Tintas e vernizes, agosto/setembro, 10-18 p.

Vandelbilt, R.T., 2015. Filler mineral reference - A guide to filler properties and uses, Vanderbilt Company, Technical Report. www.rtvanderbilt.com (accessed 08.06.2017).

Wilker, G. (2001). Dispersão de pigmentos em tintas, Tintas e vernizes, junho/julho, 40-43 p.

Wold, H. (1973) "Nonlinear Iterative Partial Least Squares (NIPALS) modelling: Some current developments." In Multivariate Analysis III. Proceedings of the 3rd International Symposium on Multivariate Analysis. Dayton, Ohio, edited by P. R. Krishnaiah, 383-407. Academic Press.

Wold, H., Lyttkens, E. (1969) Nonlinear Iterative Partial Least Squares (NIPALS) estimation procedures. Bull. Inst. Internat. Statist. 53, 29-51.

Wold, S., Sjöström, M., Eriksson, L. (2001). Chemometrics and Intelligent Laboratory Systems 58, 109-130. 